\section{Polymorphism in exon $4 a$ of the human GLUT4/ muscle-fat facilitative glucose transporter gene detected by SSCP}

\begin{abstract}
A.Muraoka1, 2, H.Sakura1, K.Kim 1, M.Kishimoto1, 2 , Y.Akanuma ${ }^{3}$, J.B.Buse ${ }^{4}$, K.Yasuda ${ }^{1,4}$, S.Seino ${ }^{4}$, G.I.Bell ${ }^{4}$, Y.Yazaki ${ }^{1}$, M.Kasuga ${ }^{2}$ and T.Kadowaki ${ }^{1}$ ${ }^{1}$ Third Department of Internal Medicine, Faculty of Medicine, University of Tokyo, Hongo, Tokyo, ${ }^{2}$ Second Department of Internal Medicine, Kobe University School of Medicine, Kobe, Hyogo, 3 Institutes for Diabetes Care and Research, Asahi Life Foundation, 161 Marunouchi, Tokyo, Japan and ${ }^{4}$ Howard Hughes Medical Institute, The University of Chicago, 5841 S. Maryland Avenue, Box 391, Chicago, IL 60637, USA
\end{abstract}

Primers/Description: Primers flanking exon 4a of the GLUT4 gene (J.B.Buse, S.Seino and G.I.Bell, in preparation) were selected and used to amplify a 252 bp fragment using PCR. The sequences of the forward and reverse primers are 5'-CAGGAAGGGAGCCACTGCTG-3' and 5'-ATCTGAAAGCCCAGGCATGG-3', respectively. The PCR products were examined for single-stranded conformation polymorphisms (SSCP) by electrophoresis in $5 \%$ polyacrylamide gel containing $1 \%$ glycerol at room temperature (Fig. 1) (1). Two alleles were noted. Direct sequencing (2) indicated that codon 130 which encodes Asn (3) was AAC (B1) or AAT (B2).

Frequency: The frequencies of B1 and B2 in 40 Japanese were 0.575 and 0.425 , respectively.

Chromosomal Localization: GLUT4 has been localized to chromosome 17p13 (4).

Mendelian Inheritance: Co-dominant inheritance was observed in two families.

Other Comments: Prior to PCR, genomic DNA was digested with HindIII, PCR reactions were heated initially at $94^{\circ} \mathrm{C}$ for $5 \mathrm{~min}$ and included 5 cycles of amplification with denaturation at $97^{\circ} \mathrm{C}$ for $1 \mathrm{~min}$, annealing at $70^{\circ} \mathrm{C}$ for $1 \mathrm{~min}$ and extension at $72^{\circ} \mathrm{C}$ for $1 \mathrm{~min}$, followed by a further 25 cycles with denaturation at $94^{\circ} \mathrm{C}$, annealing at $70^{\circ} \mathrm{C}$ for $1 \mathrm{~min}$ and extension at $72^{\circ} \mathrm{C}$ for $1 \mathrm{~min}$.

Acknowledgement: We thank Dr. Hayashi for his helpful discussions.

References: 1) Orita,M. et al. (1989) Proc. Natl. Acad. Sci. USA 86, 2766. 2) Kadowaki,T. et al. (1990) Proc. Natl. Acad. Sci. USA 87, 658. 3) Fukumoto,H. et al. (1989) J. Biol. Chem. 264, 7776. 4) Bell,G.I. et al. (1989) Diabetes 38, 1072.

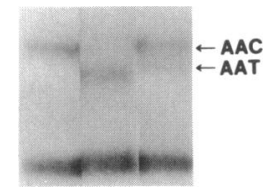

Figure 1. SSCP of exon 4a of GLUT4. The sequence of codon 130 of the two polymorphic fragments is shown.

\section{RFLPs detected with the human TCP10 gene, a homologue of a mouse t-complex gene}

K.J.Gogolin, L.G.Wright, V.J.Kolaga, L.M.Silver ${ }^{1}$ and

R.S.Spielman *

Department of Human Genetics, University of

Pennsylvania School of Medicine, Philadelphia,

PA 19104-6145 and 'Department of Molecular Biology,

Princeton University, Princeton, NJ 08544, USA

Source and Description of Clone: The TCP10 probe (pTcr66h1) is a $1.2 \mathrm{~kb}$ EcoRI fragment cloned into Bluescript. The fragment was isolated from the Maniatis $\lambda$ phage library by screening with a subclone from the region that contains the $3^{\prime}$ end of the mouse Tcp-10 transcription unit (1).

Polymorphism(s) Described: Two closely linked allelic series were detected with PvuII (2). TCP10A has four alleles with fragment sizes of $3.1,3.0,2.8$, or $2.1+0.7 \mathrm{~kb}$. (The $2.1 \mathrm{~kb}$ band is very faint). TCP10B has two alleles of 1.2 or $1.1 \mathrm{~kb}$. RFLPs were also detected with HindIII, PstI and RsaI but were not characterized in detail.

Frequency: The allele frequencies were determined in $40 \mathrm{CEPH}$ families.

A1 $3.1 \mathrm{~kb}$ allele: 0.56

A2 $3.0 \mathrm{~kb}$ allele: 0.19

B1 $1.2 \mathrm{~kb}$ allele: 0.78

A3 $2.8 \mathrm{~kb}$ allele: 0.24

B2 $1.1 \mathrm{~kb}$ allele: 0.22

A4 $2.1+0.7 \mathrm{~kb}$ allele: 0.01

Other Enzymes Tested: TCP10 did not detect polymorphisms with BgIII, EcoRI or KpnI in at least 18 unrelated individuals.

Chromosomal Localization: 6q25-q27 (1).

Mendelian Inheritance: Segregation was demonstrated for both loci in informative CEPH families.

Probe Availability: Write to R.Spielman.

Other Comments: No recombinants between TCP10A and TCP10B were observed in 86 informative meioses in CEPH families.

Acknowledgements: This work was supported by grants from the National Institutes of Health (DK35047, DK19525 and HD24383).

References: 1) Bibbins,K.B. et al. (1989) Genomics 5, 139-143.

2) Blanché,H. et al. (1989) Cytogenet. Cell Genet. 51, 963.

\footnotetext{
* To whom correspondence should be addressed
} 